\title{
LEXICAL DIFFERENCES IN GOROM LANGUAGE: A SOCIAL DIALECTOLOGY STUDY
}

\author{
Iwan Rumalean
}

\author{
iwan.rumalean@fkip.unpatti.ac.id \\ Universitas Pattimura \\ Amob, Maluku, Indonesia
}

\begin{abstract}
The present study aims to describe and explain lexical differences in Gorom language on age and professional factors in East Seram Regency, Molucca Province, Indonesia, which employs a social dialectology approach. Data were gathered using the Identity method following the linguistics characteristics identity technique. The instrument used was all 880 basic vocabulary of Gorom language. The sources for this study totaled 24 people. Furthermore, the data analysis was done using a snowball sampling technique. The study indicated that the factor of age and profession in Gorom distinguished social dialects. In the findings, farmer and adult speakers share the same lexical forms. As seen from the age factor, both farmers and adults are about the same age, making them easier to construct mutual understanding. On the other hand, civil servants and children use the same linguistic forms. Children use civil servants' speech as a reference for the kind of prestigious speech; therefore, many Gorom children dream of becoming civil servants. Yet, civil servants and children create some linguistic innovations, such as affixation to roots. It shows solidarity among the com munity and self-actualization of wide-mannered socialization.
\end{abstract}

Keywords: lexical differences, Gorom language, social dialectology

\section{INTRODUCTION}

Gorom people speak Gorom languages in Gorom Island, Manawoku Island, and Pulau Panjang Island. These three islands are known as the Gorom Islands. Administratively, Gorom Islands are spread out in three sub-districts, from 16 sub-districts in East Seram, Moluccas Province-Indonesian. Three districts are Gorom Island, East Gorom, and Pulau Panjang District. The cultivation of speech happened due to different usage, social factors, and historical factors (Rumalean, 2017, pp. 329330). Meluzzi (2015) explains that dialect is more widely used in the family domain, and its use is informal. Thus, this study's dialect is another form of language used by the community and social groups in Gorom that share the same culture, density, and usage area.

Dialectology is a linguistic branch that studies dialect. Other names that represent dialectology are geographic linguistics, regional linguistics, and geolinguistics. Dialectology has other sections of the study, such as dialectal geography, regional dialects, social dialects, and temporal dialects (Abdussalam \& Mahmud, 2014; Lauder, 2002, p.38).

This study addresses more on lexical differences in Gorom language, which employs the social dialectology approach. A social dialectology study integrates sociology and dialectology. Such integration is vital in describing and explaining the lexical differences in Gorom language from age and professional factors. The age factor consists of adults and children, while the profession factor encompasses farmers and civil servants. The lexical differences would be seen from the language used in social contacts occurring among Gorom people.

The idea above is in line with Yule (2015, pp. 22-23). There are two language essences 
in a social contact that comes into realization, namely language as a means of communication and language as cultural transmission. The realization of Gorom as the later essence, the cultural transmission, is the sociology study field. Whitehead \& Kurz (2008) explained that sociology studies individuals through a social structure, like farmers, fishermen, unemployed people, gang members, laborers, and marginalized communities.

A study on social dialect has been less preferred in Indonesia so far; most dialectologists prefer to study geographical dialects. From 1951 to 2001, there have been 219 studies on Indonesia's geographical dialects (Lauder, 2002). Thereby, some studies on social dialect which have been explored are, among others (1) Rumalean (2017) that addressed Lexicons on Relationship Greetings of Gorom Isogloss, (2) Taembo, (2016) focusing on social dialects of Indonesian, in Denpasar, Bali. This study targeted the use of both the original and borrowed phonemes in Indonesian, (3) Dewi et al. (2016, p. 1) studied Dialect of African American English in her novel entitled The Adventures of Huckleberry Finn, (4) Zulaeha (2000) focused on studying the Use of Javanese Social Dialect in Semarang Regency, Central Java, Indonesia, as seen from gender and education factors.

Other parties have not so far studied the lexical differences in Gorom based on social factors. To this background, the focus of the present study is on lexical differences in Gorom language as seen from factors of profession and age. Therefore, the study aims to describe and explain any lexical differences found in Gorom language as seen from the age and professional factors in Gorom Island of East Gorom Subdistrict and Pulau Panjang Sub-district East Seram Regency, Molucca Province, Indonesia.

\section{Studies on Lexical Differences}

There are two distinguishing characteristics of a meaning: lexical meaning and grammatical meaning (Bloomfield, 1995, p. 254). The former, lexical meaning, is about the meaning of words; thus, some also define lexical meaning as dictionary meaning or actual meaning. Meanwhile, the latter is defined as a meaning extended following cultural and contextual development. The word 'bunga' in Indonesian, for instance, lexically means a plant that grows with petals, anthers, stamens, and grown as a decorative plant. However, due to the development of the social situation, the meaning of the word 'bunga' experienced extension (grammatical meaning), into, for example, 'bunga desa,' which means a woman who is considered physically beautifulamong her community in a village, not a flower that is grown in a village.

On the other hand, the word 'TIKUS' is realized in 2 lexicons, such as 'tikUs' and 'tekUs.' The use of /i/ and /e/ as variations from this word is later involved in the body of dialectology study (Kisyani, 2004). Indonesian recognizes the lexicons of padi, gabah, beras, and nasi. While in English, there is only one form of the lexicon, which refers to the same object, which is rice. The lexicon of a plant (ethnobotany) in Bahasa Indonesia, rumput, pohon, perdu, semak, padi, and bambu (Suhandano et al., 2004, p. 229). According to the examples, the term lexicon is used as a realization from lexical meaning. Moreover, to clarify lexical differences, the term lexicon is used. For example, the lexeme 'makan' in the Gorom language is realized through 3 lexicons: ga, makang, and makan.

\section{METHOD \\ Data}

The data used in the study were 200 basic words in Gorom produced by the data source. Such utterances should include lexical forms of Gorom. Those basic words are used daily, and their meanings survive for a long time, such as eat, drink, walk, and sleep. Unlike those basic words, contemporary culture vocabulary will not survive a prolonged time, such as names for instant food brands.

\section{Data sources}

The data sources were native speakers of Gorom, totaling 24 people. Every observed area was represented by four people, each of whom delegated different social groups $(4 \times 6$ $=24$ ). They are grouped based on professions, such as farmers and civil servants, and age, such as adults and children.

The village chief's recommendation serves as the first data source. Then, the first source proposed the second one, the second to the third, and this third source suggested the fourth source. If any of the data sources did not want to recommend the following source, the researcher, in his effort, would find the next 
source by other figures in the community of the observed area. The same was done in other areas under study. Furthermore, as a source, the old er person became the main data source, while the younger one became his co-source, and for this, a female speaker was of priority. It was to anticipate any gender-related vocabulary, where a male speaker would be less knowledgeable.

The data sources were male or female speakers at the age of 7 to 65 years old, not having a speech defect (not wearing braces), born and grown up in Gorom and rarely leave the village or stay outside Gorom in a long time, speak both Gorom and Indonesian fluently, and physically healthy (Lauder, 1993).

\section{Data collection technique}

Data were collected through several techniques, such as 1) interview, 2) audio recording, 3) list of data regarding the speaker's information, like (a) resume of informants, and (b) filter of utterances from the data sources encompassing lexical forms, for this part, the Indonesian words have been previously prepared, so the sources could simply fill in their words in Gorom language.

\section{Research instruments}

The research instrument in this study is the basic vocabulary that includes lexical forms of Gorom. In total, the basic vocabulary used for the instrument is 200 words as referred to by Swadesh (1971) and Ross (2009), and relevant to the context of Gorom.

\section{Observation areas}

There are six areas for observation, namely (1) Dada village (Gorom Island), (2) Lalasa village (Pulau Panjang), (3) Ondor village (Gorom Island), (4) Miran village (East Gorom), (5) Wawasa village (Gorom Island), and (6) Amarwatu village (East Gorom). Meanwhile, every observation area is numbered using a downward vertical numbering model (Mahsun, 2014, p. 140). For a better view, the research sites can be seen in Figure 1, the map of Moluccas Province, Indonesia, and Figure 2 for Gorom Island's map.

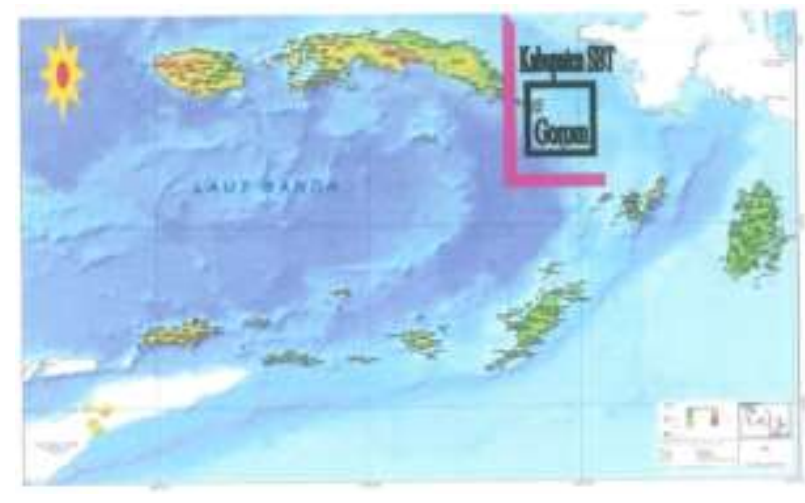

Figure 1. Map of Moluccas Province (Source: Geo SpatialBNPB, 2011, in cooperation with UNDP and SC-DRR)

Notes: _ـ Right Angle Sign is Area Border for East Seram Regency

Archipelago. The square box is Gorom (Research Site)

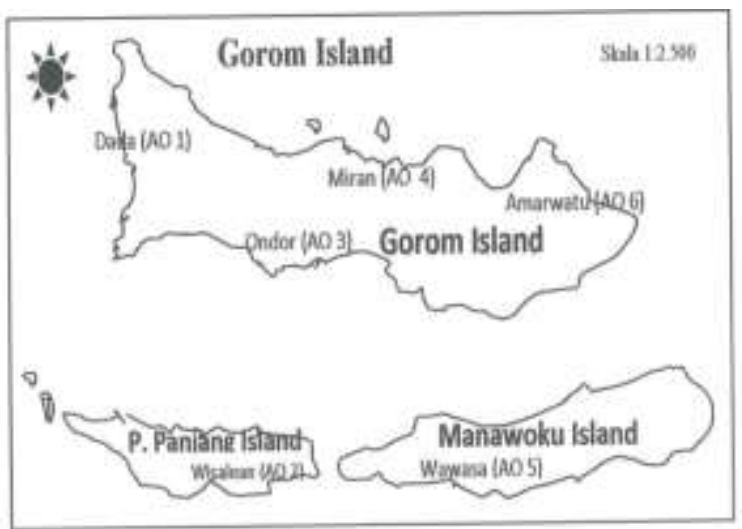

Figure 2, (Basic Map) Gorom Archipelago East Seram Regency Moluccas-Indonesia (Rumalean et al., 2018, p. 371)

\section{Data analysis}

Data analysis was done qualitatively by using the Identity method (Sudaryanto, 2015). It was performed continually from the planning of the study to the conclusion (snowball sampling). The validity of the data is tested through triangulation with the data and the source.

\section{RESULTS}

Based on the data analysis, ten lexical forms were realized through lexicon forms differently in 6 observation areas by the four social groups in Gorom. In the following subchapter, the lexicons will be described indepth details. 
Lexical Difference in Age and Profession Factors

The gloss SEDIKIT 'little' is realized with five lexicons of Gorom, such as $0 \Leftrightarrow$ ?asa, $0 \Leftrightarrow$ tca, we? an teyi, tutukinsa, and sadiki. The farmers and adult speakers use four lexicons, namely $0 \Leftrightarrow$ ?asa, otca, and sadiki. The lexicon $0 \Leftrightarrow$ ?asa is used in observation areas 1 and 2 . While the lexicon $0 \Leftrightarrow$ tca is spoken in observation area 4 , 5 , and 6 the lexicon sadiki is mostly used in observation area 3 . On the other hand, civil servants and child speakers commonly use four lexicons, such as sadiki, we?an teyi, tutukin otca, and tutuyin sa. For more details, the lexicon sadiki is used in area 1 and 3 , the lexicon we?an teyi is used in observation area 2 , the lexicon tutukin $0 \Leftrightarrow$ tca is used in observation area 4, 6, and finally the lexicon tutuyin sa is used in area 5 .

The lexicon $0 \Leftrightarrow$ ?asa is used in observation areas 1 and 2 by the farmers and adult groups. This particular lexicon is cognate with the lexicon $0 \Leftrightarrow$ tca that is mostly used in observation areas 4,5 and 6 by the civil servant group and children. These two lexical forms have been through the prothetic process of the 'addition of sound at the beginning of a word'. The lexicon $0 \Leftrightarrow$ ?asa consists of two elements, namely $0 \Leftrightarrow$ ?a + sa_o $0 \Leftrightarrow$ ?sa, so does the lexicon $\mathrm{o} \Leftrightarrow \mathrm{tca}$, which is consisted of the elements of $\mathrm{o} \Leftrightarrow \mathrm{t}+\mathrm{ca}{ }_{-} \mathrm{o} \Leftrightarrow \mathrm{tca}$. The element $\mathrm{o} \Leftrightarrow ?$ and $\mathrm{o} \Leftrightarrow \mathrm{t}$ are the short form of the word ${ }^{*} 0 \Leftrightarrow l a$ 'time', that is added to the core element of sa and ca, which is a the act of modifying (shortening) from the form of Proto-Austronesia, ${ }^{*} / \therefore \mathrm{sa}$ / *isa/ *asa 'satu' (Swadesh, 1971; Ross, 2009).

Furthermore, the lexicon tutuyin sa is used in observation area 5 by the civil servant group and children, cognate with the lexicon tutukino $\Leftrightarrow$ tca used in observation area 4 and 5 by the civil servants and children. This lexicon consists of two elements, such as tutuyin + sa. Furthermore, the lexicon tutukin otca consists of three elements, such as tutukin $+\mathrm{o} \Leftrightarrow \mathrm{t}+\mathrm{ca}$. The element tutuyin and tutukin means 'little, not long. Besides, the elementsa and ca are two forms of modification (shortening) from the form of Proto-Austronesia* $\therefore$ sa/ *isa/ *asa 'satu' (Swadesh, 1971; Ross, 2009).

We? an teyi is used in observation area 2 by the civil servant group and children, which is constructed by elements of we?an + teyi we? an teyi. The element we?an means 'a lot', while the element teyi means 'not'. As seen from the word, the element we?an is numeral, and the element teyi is an adjective that defines quantity.

The lexicon sadiki is spoken in observation area 1 by the civil servants and children, while in observation area 3 , every social group observed is found using this lexicon. The lexicon sadiki in Gorom is taken from the Ambonese Malayan, adopted from the Indonesian sedikit, through the innovation on phoneme /-e/_ /a/ to the root. The prefix of se-from Indonesian to Ambonese Malayan is shifted to sa-, as in 'sekumpul' 'sakumpul', 'sekota'_sakota', 'semua'_samua'. More, the dental phoneme / $t$ / at the final syllable, which is preceded with the velar consonant $/ \mathrm{k} /$, is omitted, like in the word 'sakit'_saki', 'sikat'_sika', 'sikut'_siku'; thus the lexicon 'sedikit'_sadiki' (Takaria and Piters, 1998).

The gloss DINI HARI 'early days' is realized in three lexicons of Gorom such as nagamari, nasosa marar, and amper siyal. Firstly, the lexicon nagamarani and nasosa marar are mostly used by the groups of farmers and adults within area 1,2,3,4, and 6 , while in observation area 5 , the lexicon nasosa marar is more commonly used. Further, the lexicon ampir siyang is used by civil servants in area 1 , 2,3 , and 6 . Meanwhile, the lexicon nagamari is used in observation area 4 , and nasosa marar is mostly spoken in observation area 5 . Moreover, the lexicon ampir siyang is used commonly by children wholive in observation area 1,3 , and 4 . The lexicon nagamarani, on the other hand, is used in area 2 and 6.

The lexicon ampir siya $\mid$ is formed by the elements of ampir + siyang. It is a borrowing from the Ambonese Malayan (Takaria \& Pieters, 1998). The word ampir/ amper in the Ambonese Malayan is originated from the word hampir in Indonesian. It is then innovated by Elicitation: afesis/aferesis "deletion of sound at the beginning of a word (Yulianto, 2012, p. 63). The word hamper, therefore is innovated and becomes ampir/amperin Gorom. On the other hand, the word siyang also adopts the Indonesian word completely without innovation. Furthermore, the word ampir is an adjective, which means 'nearly, almost, a little while, close', and siyang is an adverb, meaning morning, the sunshine 
strikes, approaching the change of the night and day, at $00.01-02.00$.

The gloss SINGLET 'singlet' is realized through four lexicons in Gorom, such as kowusa, kowus kuta la, ladan bolomina, and si llet. Farmers and adults use both kowusa and ladan bolomina. While the lexicon kowusa is used in observation area DP 1, 2, 3, 4 and 6, ladan bolomina is spoken mostly in observation area 5 . In this finding the civil servants and children use two lexicons, kowus kuta la and si let. The lexicon kowus kuta la is used in observation area 1,2, 4, 5, 6, and the lexicon si let is spoken in observation area 3 .

Furthermore, the lexicon kowusa adopts the Indonesian word and is the cognate with kowus kuta a. It consists of two elements, namely kowus + kuta la. Kowus "kaus" is commonly known as short-sleeved clothes or $\mathrm{T}$-shirt, yet the long-sleeved ones are also available as variations, without hooks nor collars. It has a round neck, but some have a vneck as variations (Nakal, 2016). Kuta la is from the word kuta| 'woman's underwear that covers breasts. Therefore, kowus kuta la means shirt worn by men for covering the upper parts of their body.

The lexicon ladan bolomina is a Gorom word, which consists of several elements, such as [ladan-] + [bo-] + [lomin-] + [-a]. Firstly, the element ladan as a base word for 'clothes'. Then, the lexicon bolomin is made up of two elements; bo + lomin. The element boas (the prefix) means 'in', and the element lomin (a base word) means 'inside, full'. The element [a], on the other hand, is a suffix that is to confirm. Secondly, the lexicon si let adopts an English word, that means a piece of shirt worn to cover the inside and upper part of the body.

The gloss PENJABAT 'officials' is realized in two lexicons; warnemena and pejabata. The latter, pejabata, is mostly used by farmers, civil servants, and adults in all observation areas. Further, the farmers and adults in observation area 4 are found to use two lexicons, warnemena and pejabat. Meanwhile, the farmers and adult speakers in observation area 4,5 , and 6 use the lexicon warnemena. On the other hand, children in all observation areas use pejabata to denote officials.

The lexicon warnemena is made up of the word warnemen (a base noun) which means 'position'. This lexicon has undergone a morphological process in its base form [warnemen-] + [-a] as suffix, that adds a meaning of 'one, something'. In this case, the duty mandated to a person within a period of time is the position for a governmental executief chief (Village Chief).

The lexicon of BAMBU KECIL "small bamboo" is realized in three Gorom lexicons, namely $\leftarrow \Leftrightarrow$ lura, yimaka, and bambu kacil. $\leftarrow \Leftrightarrow$ lura is used by every social group observed in this study in almost every observation area, such as $1,2,4,5$, and 6 . Meanwhile, yimaka is used by farmers and adults in observation area 3. Finally, the lexicon bambu kacil is used mostly by civil servants and children in area 3.

Another lexicon, METEOR/ SHOOTING STAR "meteor" is realized in three Gorom lexicons, such as tila $\Leftrightarrow$ ra natewat, binta $\mid$ jatu, and arumbawura. The first lexicon, tila $\Leftrightarrow$ ra natewat is used by farmers and adult speakers in observation area $1,2,5$, and 6 , while the lexicon binta $\mid$ jatu is used in observation area 3. Another lexicon, arumbawura is mostly spoken in observation area 4 by every social group, and tila $\Leftrightarrow$ ra natewat, on the other hand, is used in observation area 5 by all social groups. Besides, binta $\mid$ jatu is used in the area 3 by all groups.

The lexicon tila $\Leftrightarrow$ ra natewat may be an originally Gorom lexicon, since none of the known related (family connection) languages which is cognate with this lexicon. The lexicon consists of two elements, such as tila $\Leftrightarrow$ ra and natewat. The first element is also made up of two elements, [tila $\Leftrightarrow \mathrm{r}-]+[\mathrm{a}-]$. The element [tila $\Leftrightarrow r-]$ means 'star', while the element [a-], a suffix, which means 'something, thing'referring to the root. Therefore, tila $\Leftrightarrow$ ra means a star. The latter element, natewat, is a Gorom word that means 'falls, sticking into the ground'. Thus, the meaning of tilara natewat is a 'meteor which falls and sticks into a part of the earth, and causes a bright light as it is through the earth's atmosphere". The light looks like a star, so it is referred to as tilar 'star'.

The gloss TANJUNG 'cape' is realized in two Gorom lexicons, namely suwaro?, and tanju la. The former is mostly spoken by the group of farmers and adults in observation area $1,2,4,5$, and 6 . While in area 3 , the word tanju la is more common. The civil servant group and children tend to use the lexicon 
tanju la in observation area 1 and 3 , and the lexicon suwaro? in observation area $2,4,5$, and 6.

The former lexicon suwaro,? is a Gorom lexicon because it is not cognate with other languages. This lexicon is a singular form in Gorom.

Meanwhile, the lexicon tanju la is derived from an Indonesian word 'tanjung', which is then through paragogein supplying [-a] suffix in Gorom, which means 'something, one'. The pattern of the word tanju la, therefore, is [tanjul-] + [-a] tanjula 'a cape, cape'. Following this explanation, borrowed nouns in Gorom are ended with suffixes /a/, /ra/, /o/, /ro/ and /i/, as in botal_botala 'bottle', suwar suwara, suwaro? 'cape'. Unless theyare added with suffixes, their meanings will change or will not be acceptable in Gorom. For example, the word suwar has two different meanings, 'cape, and push', therefore to distinguish the two meanings, adding suffix /a or o/ or /i/ is necessary, thus it becomes suwara/ suwaro? 'cape', and suwari? 'push him'.

The gloss BERDAHAK 'phlegm' is realized in three Gorom lexicons, such as naguwa?, na?alahar and berdahak. The group of farmers use three lexicons naguwa?, naguwak, and na?alahar. The former is mostly spoken in observation area $1,2,4$, and 6 , while the lexicon naguwak is commonly used in area 3.

On the other hand, the civil servant group use three lexicons as well, namely naguwa?, na?alahr, and berdahak. In this group of speakers, the first lexicon naguwa?, is mostly used in observation area 1,2, 4, and 6, while the lexicon berdahak is used in the area 3 , and the other lexicon, na?alahar, is commonly used in observation area 5 .

Similar to the farmers, the group of adults uses the same lexicons as the farmers, naguwa?, naguwak, and na?alar. The lexicon naguwa? is used in observation area $1,2,4$, and 6 while naguwak is mostly spoken in observation area 3 , and thelexicon na?alahar is used in the area 5.

On the other hand, the children speakers commonly use the same lexicons as those of the civil servants, such asnaguwa?, berdahak, and na?alahr. The lexicon naguwa? is used in observation area 1, 2, 4, and 6 berdahak is used in observation area 3 , and the lexicon na?alahar is used in observation area 5.

For more details, the lexicons naguwa?/naguwak, and na?alahar can be originally from Gorom language, since it is found not being cognate with other Proto languages. The lexicon naguwa?/naguwak are made up of two elements; [na-] + [-guwa (-?, $\mathrm{k})$ ]. Meanwhile, the element [na-] is a prefix which means 'doing something'. The element guwa $(-?, \mathrm{k})$ is a root, that means throwing phlegm out of the mouth. Therefore, naguwa?a/naguwak is to throw out/try to throw out phlegm.

The lexicon na?alahar, on the other hand, is formed by two elements, such as, [na-] + [?alahar]. The element [na-] is a prefix that means 'doing something', while the element [?alahar] is a root that means 'mucus' from the mouth. Therefore, na?alahar means discharging or trying to discharge mucus out of the body (throat). Finally, berdahak is a lexicon derived from the Indonesian word, which is made up of two elements, [ber-] as a prefix, and [-dahak] as its root.

The gloss BEGITU 'so' is realized in 5 lexicon forms in Gorom, such as sontoyira, sontora, $\mathrm{pi} \Leftrightarrow \mathrm{ra}$, huntura, and bagitu. Within the group of farmers, 4 lexicons are more commonly used, such as sontoyira, sontora, huntura, and $\mathrm{pi} \Leftrightarrow \mathrm{ra}$. The lexicon sontoyira is used in observation area 1 and 3 . The lexicon $\mathrm{pi} \Leftrightarrow$ ra is used in observation area 2 , sontora is spoken more in observation area 4 and 6 , while the lexicon huntura is used mostly in area 5.

The civil servant group use all the 5 lexicons sontoyira, sontora, pira, huntura, and bagitu. For this group of speakers, the lexicon sontoyira is used in observation area 1 , the lexicon sontora is used in observation area 4 and $6, \mathrm{pi} \Leftrightarrow$ rais spoken in area 2 , the lexicon huntura is used in observation area 5 , and bagitu is used in observation area 3 .

The adult speakers use 4 lexicons, namely sontoyira, sontora, $\mathrm{pi} \Leftrightarrow \mathrm{ra}$, and huntura. The lexicon sontoyira is used in observation area 1 and 3. Meanwhile, the lexicon sontora is used in observation area 4 and 6 , the lexicon pi $\Leftrightarrow$ ra is used in area 2 , and the lexicon huntura is used in observation area 5.

Similar to the civil servant group, children speakers use all the five lexicons, such 
as huntura, pi $\Leftrightarrow$ ra, bagitu, sontora, and suntura. The lexicon huntura is used by this group in observation area $1, \mathrm{pi} \Leftrightarrow \mathrm{ra}$ is used in observation area 2 , the lexicon bagitu is used in area 3 , the lexicon sontora is used more commonly in observation area 4 and 6 , and the lexicon suntura is used in observation area 5.

Furthermore, both sontoyira and sontora are made up of two elements, namely [sonto-] and [-yira/ra]. The element sonto is a root that means 'example', and the element [yira/ra] is a suffix which means 'that'. The word sotoyira/ sontora therefore means 'like that, something like that, like the example'. The word sonto has been innovated through assimilation and vowel attenuation. The assimilation process is done by changing the phoneme /c/ _ /s/, while the vowel attenuation is realized by eliminating the sound /h/. Thus, the Indonesian word contoh is changed into sonto in Gorom. Such innovation can also be found in other forms, like central that is pronounced sentral, centimeter pronounced as sentimeter. Yet, not every Indonesian word initiated with phoneme /c/ is innovated and changed to /s/, as in the word cuma-cuma which is constantly pronounced cuma-cuma, and cara that is pronounced cara.

The lexicon huntura is made up of elements of [huntu-] + [-ra]. The element huntu- is a root which means like that, something like it, as exemplified'. The element ra-, on the other hand, is a suffix, which means 'that'. The lexicon $\mathrm{pi} \Leftrightarrow$ ra is also made up of two elements; $[\mathrm{pi} \Leftrightarrow-]+[-\mathrm{ra}]$ as a suffix. As a root, $\mathrm{pi} \Leftrightarrow$ ?means 'something like that, like it'. The suffix [-ra] means 'that'. Therefore, the form $\mathrm{pi} \Leftrightarrow \mathrm{ra}$ if translated following its structure will mean seperti itu or begitu itu. However, since the word itu in seperti itu/ begitu the same as itu in suffix [-ra], their meanings are combined. The process of changing sound in language is called assimilation (Yulianto \& Totong, 1989, p. 69).

The lexicon bagitu 'like that' adopts the Ambonese Malayan, that is also derived from the Indonesian word 'begitu'. This phenomenon has been through the innovation process to the coda, in which /-e/ becomes /a/, such as *begitu bagitu. Some other forms of Ambonese Malayan words are *belum balong, *besar basar, *kecil kacil, *kemarin kamaring.

The gloss BEGINI 'like this' is realized in five lexicons in Gorom, namely sontoyire, sontore, hunture, $\mathrm{pi} \Leftrightarrow \mathrm{re}$, and bagini. The group of farmers and adults usually use three of the lexicons, such as sontoyire, sontore, and $\mathrm{pi} \Leftrightarrow \mathrm{re}$.

The lexicon sontoyire is used by farmers and adults in observation area 1 and 3 , the lexicon $\mathrm{pi} \Leftrightarrow \mathrm{ra}$ is used in area 2 , while the lexicon sontore is found in area 4 and 6 , and the lexicon sunture is spoken in observation area 5. The civil servant group and children tend to use four lexicons, such as sontore, $\mathrm{pi} \Leftrightarrow \mathrm{re}$, hunture, and bagini. The lexicon sontore is mostly used in observation area 4 and $6, \mathrm{pi} \Leftrightarrow$ re is usually used in the area 2 , the lexicon hunture is used in observation area 1 , and bagini is spoken mostly in observation area 3 .

Both sontoyire and sontore are formed by two elements, such as [sonto-] and [yire/re]. The first element, sonto, is a root meaning 'example', and the last element [yire/re] is a suffix which holds a meaning 'this'. Therefore, the lexicon sontoyire/ sontore means 'like this, something like this, as exemplified'. The root sonto is a form that has been through assimilation and phoneme attenuation processes. The assimilation process is done by changing the sound of /c/ /s/, while the phoneme attenuated is the sound of $/ \mathrm{h} /$. Therefore, the word contoh from Indonesian is made into sonto in Gorom. Such innovation can also be found in other words, like central which is pronounced as sentral, centimeter which which is pronounced as sentimeter. However, not every phoneme /c/ in Indonesian is innovated into /s/, like in cuma-cuma that remains cuma-cuma, and cara that remains as it is. Innovations are made for vocabulary that are not originally Indonesian words.

Furthermore, the lexicon hunture is formed by two elements, namely [huntu-] + [re]. The former, huntu-, is a root that means 'like this, as it is, as exemplified', while the element re- is a suffix that means 'this'. The lexicon $\mathrm{pi} \Leftrightarrow \mathrm{re}$, on the other hand, is made up of the root $[\mathrm{pi} \Leftrightarrow-]$ and [-re] as its suffix. $\mathrm{Pi} \Leftrightarrow$ ? means 'as this, and like this'. The suffix [re] means 'this'. Therefore, if $\mathrm{pi} \Leftrightarrow \mathrm{re}$ is translated as it is structured, it will mean 
seperti ini or begini ini. However, the meaning of this or ini in the form seperti ini/ begini is the same as that of the suffix [-re], so the meaning is combined. The process of changing the language sounds is called assimilation (Yulianto \& Totong, 1989, p. 69).

\section{DISCUSSION}

The results reveal that the social group of farmers commonly uses different forms of lexicon from the civil servant group. Moreover, as seen from the age factor, adults tend to use different forms of lexicon from those used by the group of children. In other words, the group of farmers and adults share the same forms of lexicon, while the civil servant group share the same forms of lexicon with the group of children. It may happen because the group of adult speakers are at about the same age as the group of farmers, compared to the group of children. On the other hand, the Gorom's children mostly aspire to be civil servants, not farmers. Therefore, they tend to imitate the language of civil servants and consider them as idols. Civil servants may be preferred because they have higher social status than farmers.

In line with the previous idea, the use of lexical forms in Gorom can be seen from the social factors and social classes. Social factors include farmers, civil servants, adult speakers and child speakers, labors, and marginalized people. Meanwhile, the social classes include policy functionaries in a tribal council like a king, village organization (village chief), imams (a leader in collective prayer), preachers, and chief of hamlet (lowest position in the tribal council). The social groups that have been investigated based on the social factors have been found using different forms of lexicon. Meanwhile, the social groups that are observed based on their social classes have not shown the use of different forms of lexicon. The different use of lexical forms is a variation or dialect, not a different language because every member of the community still demonstrate mutual understanding (mutual intelligibility).
Sharma \& Rampton (2015) explain that social status uses lec (social registers) in a particular language, marks out its social group. Therefore, one of the features of social groups in Gorom is their social dialect.

The language variation as used by social groups has also been previously indicated by Labov in 1962, through the use of the accent $/ \mathrm{r} /$. Labov has investigated three different supermarkets by classifying the respondents of workers and buyers based on their social status; low-intermediate, intermediate, and upper-intermediate classes. He has constructed a dialect map in New York City which indicates that the accent $/ r$ is used by speakers from lower class (laborers) limited to only formal occasions. This is to show that they are also educated to some extent. The intermediate and upper intermediate classes, on the other hand, use the accent $/ \mathrm{r} /$ in every situation (Labov, 2006, p. 40-41).

\section{CONCLUSION}

The lexical forms in Gorom are used differently by different social groups in Gorom. The social groups that use different lexicons in Gorom are those categorized by social factors (professions), such as farmers, civil servants, adults, and children. Yet, the social groups that are based on the social classes use similar lexicon forms.

The group of farmers and adults use the identical lexicons. Furthermore, the civil servant group and children speakers use the same lexicon forms. The similar lexicons spoken by the social groups happen as a manifestation of solidarity within the group of the same age and thought. As seen from the age factor, for example, the group of farmers and adults are at about the same age, around 40 to 60 years old. Meanwhile, the civil servant group and children are at the minimal age of 20 to 60 years old. The minimal age of civil servants is, therefore, at close range to the age of children.

\section{REFERENCES}

Abdussalam, A., \& Mahmud, S. (2014). gayo language is old malay (a dialectology study: the language change). Englisia: Journal of Language, Education, and Humanities, 1(2).. 
BNPB, UNDP, SC-DRR. (2011, 25 September). Geospasial-BNPB-peta administrasi provinsi di Kepulauan Maluku. Diperoleh dari http://geospasial.bnpb.go.id/2009/11/25/petakepulauan-maluku/. Jakarta: BNPB,UNDP,SC-DRR.

Bloomfield, L. (1995). Bahasa (Language). (diindonesiakan oleh I. Sutikno). Jakarta: PT. Gramedia Pustaka Utama.

Dewi, I. K., M.R. Nababan., Riyadi, S., Djatmika. (2016). Terjemahan dialek African American English dalam novel the Adventures of Hucleberry Finn. Proceding International Seminar Prasasti III: Current Research in Linguistics.Universitas Sebelas Maret Surakarta. Retrieved from https://jurnal.uns.ac.id/prosidingprasasti/index.395-403.

Kisyani, L. (2004). Bahasa Jawa di Jawa Timur Bagian Utara dan Blambangan kajian dialektologis. Jakarta: Pusat Bahasa RI Departemen Pendidikan Nasional.

Labov, W. (2006). The social stratification of English in New York City (Second Edition). Cambridge, New York, Melbourne, Madrid, Cape Town, Singapore, São Paulo: Cambridge University Press.

Lauder, M. R. M. T. (1993). Pemetaan dan distribusi bahasa-bahasa di Tangerang. Jakarta: Pusat Pembinaan dan Pengembangan Bahasa.

Lauder, M. R. M. T. (2002). Reevaluasi konsep pemilah bahasa dan dialek untuk bahasa Nusantara. Makara Sosial Humaniora. 6(1). Di peroleh dari www.jurnal.vi.ac.id/humanities/article/ viewFile/31/27.

Mahsun. (2014). Metode penelitian bahasa tahapan strategi metode dan tekniknya.(edisi revisi). Jakarta: PT. Raja Grafindo Persada.

Meluzzi, C. (2015). Dialects and linguistic identity of Italian speakers in Bozen. Globe: A Journal of Language, Culture and Communication. 1(1),1-16. Doi: https://doi.org/10.5278/ojs.globe.v1i0.697.

Nakal, Republik. (2016). Pengertian kaos. Diperoleh dari http://grosirkaosnakal. blogspot.com/2016/05/pengertian-kaos-definis-kaos-arti-kaos.html.

Rumalean, I. 2018. Gorom Language's Phonological Differences Viewed from Age and Occupation Factors: Socio-dialectology Study. Atlantis Press, 2nd Social Sciences, Humanities, and Education Conference (SoSHEC 2018). 2(222) 370-374. Retrieved from file:///C:/Users/ASUS/AppData/Local/Temp/25903385.pdf.

Rumalean, I. 2017. Leksikon sapaan isolek Gorom di Kabupaten Seram Bagian Timur: Kajian Dialek Sosial. Bahasa dan sastra dalam konteks Global, e-Prosiding Seminar Nasional. (p.p 329-340). Jember-Jawa Timur-Indonesia: PS-PBSI-FKIP Universitas Jember. Retrieved from https://jurnal.unej.ac.id/index.php/fkip-epro/issue/view/505.

Ross, H. (2009). Proto-Austronesian (PAN) languages. Wikepedia-Encyclopedia Indonesia. Retrieved from http://www.en.wikepedia.org/w/index.php?title=Proto-Austronesia language\&oldid=7 $\underline{87537294}$.

Sudaryanto. (2015). Metode dan aneka teknik analisis bahasa pengantar penelitian wahana kebudayaan secara linguistis. Yogyakarta: Senata DharmaUniversitty Press.

Suhandano., M. Ramlan., Soepomo, P., Heddy, S. A-P. (2004). Leksikon etnobotani bahasa Jawa. Jurnal Humaniora. 16.(3) 229-241. Universitas Gadjamada. Diperoleh dari http://www.jurnal.ugm.ac.id/jurnal-humaniora/article/download/1303/1105. 
Sharma, D. \& Rampton B. (2015). Lectal focusing in interaction: A new methodologi of stayle variation. Journal of English Linguistics. 43(1) 3-35. Retrieved fromhttp://eng.sagepub.com/. Queen Mary University of London, London:Sage Publication.

Swadesh, M. (1971). Apendix: proto-Austronesia Swadest List. Wikepedia-Wiktionary Article Swadest list. Retrieved fromhttp://www. en.wiktionary.org/wiki/Appendix:ProtoAustronesia Swadeshlist.

Taembo, M. (2016). Kajian dialek sosial fonologi bahasa Indonesia. Journal Kandai. E-Jurnal Kantor Bahasa Sulawesi Tenggara-Kementerian Pendidikan dan Kebudayaan. Diperoleh dari http://ojs.badanbahasa. kemdikbud.go.id/jurnal/index.php/kandai/article/view/68/14.

Takaria, D. \& C. Pieter. (1998). Bahasa Melayu Ambon-Indonesia. Jakarta: Pusat Pembinaan dan Pengembangan Bahasa.

Whitehead, K. \& Kurz, T. (2008). Saints, sinners and standards of femininity: Discursive constructions of anorexia nervosa and obesity in women's magazines. Journal of Gender Studies. 17(2)345358. Retrieved from https://catalog.flatworldknowledge.com/bookhub/ reader/ 16891?e=barkan-ch01s02.

Yule, G. (2015). Kajian bahasa. (edisi kelima). Diterjemahkan oleh Astri Fajriah. Yogyakarta: Pustaka Pelajar.

Yulianto, B. (2012). Fonologi generatif teori dan aplikasinya. Surabaya: Lembaga Penelitian Universitas Negeri Surabaya.

Yulianto, B., \& Totong T. (1989). Fonologi. Surabaya: Jurusan Pendidikan Bahasa dan Sastra Indonesia FPBS-IKIP Surbaya.

Zulaeha, I. (2010). Dialektologi: Dialekgeografis dan Dialek sosial. Yagyakarata: Graha Ilmu. 